\title{
Isn't It Ironic? Research Rewards And Teaching Taxes
}

\author{
Blakely Fox Fender, Ph.D., Millsaps College, USA \\ Susan Washburn Taylor, Millsaps College, USA \\ Kimberly Gladden Burke, Ph.D., Millsaps College, USA
}

\begin{abstract}
The use of person-specific data for economists across all types of public academic institutions provides several insights into the academic wage equation for economists. First, this study confirms the alignment of the academic incentive structure with the underlying value of scholarship in an academic institution, i.e. scholarship pays off. Interestingly, though, the richness of this data set allows for a better understanding of that payoff. For while economists at doctoral granting institutions earn more on average than their counterparts at non-doctoral granting institutions, the marginal benefit for additional publications is higher for those economists at non-doctoral granting institutions.
\end{abstract}

Most importantly, the study validates the recent findings of Binder et al. (2012) that the incentive structure at academic institutions imposes a teaching tax. Whether at doctoral or non-doctoral granting institutions, the marginal cost of teaching undergraduates is significant although there is a positive return to award-winning teaching. Thus, despite the inherent educational mission of the Academy, this study supports the ironic conclusion teaching imposes a tax on the academic economist.

Keywords: Research Rewards and Teaching Taxes; Academic Wage Equation; Financial Returns to Teaching and Research

\section{INTRODUCTION}

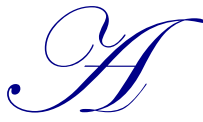

$\mathrm{t}$ the heart of the Academy's mission is the commitment to excellent education at both the undergraduate and graduate levels. Often explicitly stated, but always implied, is the idea that the road to excellent education is paved with faculty members conducting scholarly research that keeps them current in their disciplinary fields. The existence and significance of scholarly research as the avenue to excellent education is affirmed by an incentive structure for faculty which provides positive financial returns to scholarship. The corollary question, though, is whether the incentive structure also provides positive returns for the essence of education, teaching. The results of this study indicate that it does not.

Positive financial returns to scholarship have been well documented. That researchers have principally focused on the returns to the quantity and quality of scholarship reflect the more pragmatic difficulties of accessing data on specific teaching and service loads. As a result, many studies employ homogeneous samples of either economists at research universities or of academics at a single institution. In either case, teaching and service commitments are assumed similar. Binder, Chermak, Krause and Thatcher (2012) extend the literature by estimating a wage equation for academics which specifically controls for teaching and service loads. In the context of all academics at a single institution, they find financial advantage to scholarship and administrative service while a penalty for teaching. This paper examines the generalizability of this conclusion to economists at multiple institutions with different research emphases.

Using a unique data set with person-specific data for a cross section of economists at all types of public institutions, the results of this paper provide new insights into the pay structure for academic economists. Although 
other studies have examined the financial returns to scholarly productivity, this rich database also allows a rare examination of the degree to which the quantity of teaching different audiences (undergraduates versus graduate), the quality of teaching, and different levels of service to the institution generate financial returns for the academic economist. Results suggest that faculty reap rewards for scholarship, pay a teaching tax, and incur positive returns to some types of service.

Section II of the paper places this contribution in the setting of previous work on the subject. Sections III and IV present the data, the model and empirical findings. As the data includes economists at a wide variety of academic institutions, the paper provides an examination of the teaching tax disaggregated for economists at doctoral and non-doctoral granting institutions in Section V. The conclusion is presented in Section VI.

\section{THE SETTING}

The economics literature is replete with studies examining the academic wage equation. A fundamental challenge in these studies is data collection and the emphasis in these studies varies depending upon what data is employed. Some studies have examined only economists. For example, Bratsberg, Ragan and Warren (2010) examine a 30-year history of faculty at five Ph.D. granting economics departments. Moore, Newman and Turnbull (1998) examine economists at several Ph.D. granting institutions whose faculty were willing to participate in the study. O'Keefe and Wang (2013) use economists in the University of California system and arguably have a greater diversity in type of institution, though all are in the same broad geographical area and operate under the same broad governance system. Other studies, however, have examined wage equations for all faculty at a single institution or across institutions. Carlin, Kidd, Rooney, and Denton (2013) examine wage structure of all faculty at a large state university while Barbezat (2003) employs data for all faculty over a variety of institutions. Whether examining wage equations for economists or across many disciplines, the samples were chosen either because participants provided salary data or because salary data was publicly available. The result in either case typically yields samples which are fairly homogeneous, limited typically to scholars at research-oriented institutions.

Another challenge in estimating academic wage equations is collecting relevant data to explain variations in salary. Publication data (both quantity and quality) and citations of work can be readily found at EconLit or Social Sciences Citation Index (SSCI), respectively. However, person-specific information on teaching loads and service are much more challenging to gather and thus are often assumed constant across individuals. Barbezat (2003) employs survey data from the National Study of Postsecondary Faculty. Bratsberg et al. (2010) and Moore et al. (1998) glean data from resumes provided by participants. Carlin et al. (2013) employ data from a large university's mandated study. Several of these studies capture quality of teaching through a dummy variable if the individual received a teaching award but the data does not allow for a distinction between the impact of teaching graduate versus undergraduate courses on compensation nor do they reflect the impact of teaching in the summer on base salary. Thus quality teaching is reflected, but not quantity of teaching, nor is there a distinction between the impact of teaching graduate students or undergraduates. Similarly, service to the institution is difficult to capture quantitatively. The existing literature finds positive returns to service as department chair, prior department chair, or prior dean (Binder et al. (2012), Bratsberg et al. (2010), and Moore et al. (1998)). Carlin et al. (2013) include a service award as a control variable, but find an insignificant effect on returns to receipt of that award. Likewise, Binder et al. (2012) find the fraction of time devoted to university service to be statistically insignificant, other things constant.

The data set for the current study provides insights into the wage structure of economists not captured in the existing literature. First, it includes economists at varying types of public institutions (rather than Ph.D. granting institutions only). Thus, we are able to add to the literature an examination of economists for whom scholarship may be one component of their compensation structure but not the predominant factor. Second, the data set includes specific variables to reflect undergraduate, graduate and summer teaching loads. Finally, the data set expands the concept of service to include not only the duties of administrators such as department chairs, but also the more routine service obligations of faculty such as committee assignments and committee chair. These enhancements allow a more nuanced examination of the role teaching and college service play in compensation. 


\section{THE DATA}

The genesis of this data set is person-specific data collected from a web based survey conducted in Spring, 2003. It resulted in several papers examining the impact of teaching and service on publication in peer reviewed journals. ${ }^{1}$ The survey asked for a variety of information related to economists' human capital and workplace characteristics. The time-varying characteristics were limited to the five-year period from 1998 -2002. In order to measure individual productivity, publication information for each respondent was gathered from the EconLit database.

Because the original survey did not ask respondents to give permission to use their information in a wage estimation context, all respondents employed at public institutions were e-mailed a request to give permission to use their responses in the current study. Only those who responded positively are included here, yielding a sample size of 188. Though a subset of our original sample, characteristics of the subset are quite similar to those of the original. Gender, experience, and teaching loads are almost identical. In addition, there are roughly equal numbers of participants at doctoral and non-doctoral granting institutions.

Though a smaller sample size than in some studies, it is consistent with that of O'Keefe and Wang (2013) and Moore et al. (2007). Since small sample sizes may cause regression estimates to be sensitive to specification, we estimated a number of specifications in preliminary research. We find the quantitative results presented here to be consistent across specifications.

\section{Compensation}

Nine-month base salary for each survey respondent for the 2003-2004 academic year was gathered from public sources. The compensation measure excludes fringe benefits, summer pay, or administrative compensation. As presented in Column 1 of Table 1, on average, faculty members earned \$87,336 in the 2003-2004 academic year. Professors at doctoral granting institutions earn more (roughly $\$ 96,000$ ) relative to professors at non-doctoral granting institutions (roughly \$77,000) All variable definitions can be found in Table 2.Teaching Teaching

\section{Characteristics}

Unique to this data set is person-specific information on teaching load. Most other literature examines a like group of economists (primarily those at doctoral granting institutions) who would have similar teaching loads both in terms of number of classes taught and division of classes amongst graduate and undergraduate students. Given that our sample is more diverse (only $52 \%$ of the sample teaches at doctoral granting institutions), it is instructive to examine not only the impact of teaching awards on earnings but the number and distribution of credit hours as well. The typical economist in this sample has an undergraduate load of roughly 10.4 credit hours, a graduate load of 2.8 credit hours, and a summer load of 1.5 hours. In addition, the average economist has received at least one teaching award during his or her academic career. Teaching awards are expected to increase earnings, though the impact of teaching load and composition of courses is unclear a priori.

\section{Service Load}

Service to the institution (committee work) is a component of the academic life which may be fairly similar at a doctoral granting institution but may vary more when considering a larger diversity of institutions. In addition, leadership, as compared to committee membership, is likely to have a positive impact on earnings. While other studies have captured time spent as department chair (an average of almost 3 years for those who have served in this capacity), this data set also includes the individual's total number of committees (2.6 on average) and committee chair assignments (0.9).

${ }^{1}$ See Fender, Taylor and Burke (2005) and Taylor, Fender and Burke (2006). 


\section{Scholarly Productivity}

Without exception, the literature indicates that for economists scholarly productivity in the form of peer reviewed publications positively impacts earnings. The differences in the literature lie in how the measure of productivity is defined. Typically, there is some combination which reflects both quantity of scholarship and its quality. Moore et al. (1998) provide a detailed breakdown of publications by quantity and quality (Level 1, Level 2 and Other publications) while O'Keefe and Wang (2013) employ similar but slightly different measures. Hammermesh and Pfann (2012) explore the role of citations as a measure of quality in determining salary.

The current framework creates a scholarly productivity index, $Q C$ Publications, which measures individuals' number of quality and coauthor adjusted peer-reviewed publications. ${ }^{2}$ The number of refereed journal articles is used as a baseline for each professor's research activity. This baseline number of publications is then adjusted for quality and co-authorship. The quality ranking is derived from Laband and Piette's (1994) ranking of 130 journals with a value of 0.05 entered for those journals not appearing in their ranking. Following Bodenhorn (1997), the quality weighting used in this analysis is the square root of the modified Laband and Piette adjustment factor. This allows a consistent ordinal ranking of the journals but the cardinal weight differentials are smaller. To adjust for coauthors, total publications were divided by the number of authors. QC publications is thus calculated as

$$
\text { QC Publications }_{i}=\sum_{j=1}^{n}\left[\frac{p_{i, j} q_{j}}{A_{i, j}}\right]
$$

where $\mathrm{p}=$ publications, $\mathrm{q}=$ the square root of the journal quality adjustment, $\mathrm{A}=$ number of authors, $\mathrm{i}=$ individual, and $\mathrm{j}=$ journal.

Though peer reviewed publications are clearly the coin of the realm within the field, economists also publish books. Thus, we also include the total number of books published as an explanatory variable. The aggregate sample averaged 1.05 books. Personal and Human Capital Characteristics

The extant literature is inconclusive regarding the impact of seniority and experience on faculty compensation. Barbezat (2004) finds that seniority and experience both have positive and nonlinear effects on salary while Moore et al. (1998) show negative effects to both measures. The current sample is an experienced group with average experience of 19.6 years and 16.8 years seniority at the current institution.

Eighty percent of the current sample are male. As with the role of seniority and experience, the impact of gender on earnings is mixed in the literature. Barbezat (2003), Blackaby, Booth and Frank (2005) and Takahashi and Takahashi (2011) all find a gender gap in compensation for economists, though Moore et al. (2007), O'Keefe and Wang (2013), and Bratsberg et al. (2007) find no such gap.

Three variables are included in our data set as measures of human capital. Top Ph.D. program is a dummy variable for graduation from a top Ph.D. program. Blackaby et al. (2005) and Moore et al. (1998) find a similar variable to positively impact base salary. Review before $P h D$ reflects the number of manuscripts under review at refereed journals before the first academic position while Years to Ph.D. reflects the number of years taken to obtain the terminal degree. Both of these variables are new to the literature. The former is hypothesized to have a positive impact while the latter is assumed to be negative. Finally, we include a dummy variable, Consulting, to reflect individuals who provide consulting services. The literature is largely silent on the impact of outside consulting. Its impact is uncertain a priori.

\footnotetext{
${ }^{2}$ This index is similar to that employed in Fender, Taylor and Burke (2005) and Taylor, Fender and Burke (2006), though it reflects a cumulative rather than annual measure of scholarship.
} 


\section{THE ACADEMIC WAGE MODEL AND ESTIMATION}

We use a standard human capital earnings model to examine the wage equation for academic economists. Following this approach, salary can thus be modeled as

Salary $=\mathrm{f}($ Teaching Characteristics, Publication History, College Service, Personal Characteristics, Institutional Characteristics)

where Teaching Characteristics, Publication History, College Service, Personal Characteristics, and Institutional Characteristics are each vectors that contain variables described in the previous section. To examine the wage equation, an ordinary least squares model is employed. The dependent variable is the natural log of the 9-month salary from the 2003-2004 academic year. Regression results are found in Column 1 of Table 3.

Consistent with previous studies, there are positive returns to scholarly productivity both in terms of peer reviewed publications and books. Publishing an additional quality-coauthored adjusted publication leads to an increase in base pay of 0.6 percent, and publishing another book leads to a payoff of 2 percent. Evaluating salary at the aggregate mean, one additional quality adjusted publication leads a $\$ 507$ increase in base salary while an additional book results in an increase in base salary of approximately $\$ 1,310$.

Distinctive to the current study is the ability to directly estimate the impact of additional teaching on the economist's salary. Teaching additional undergraduate hours and teaching in the summer both significantly reduce base salary. When evaluated at the mean, one additional 3-hour undergraduate course reduces base salary by roughly 3 percent or $\$ 2,725$. Teaching an additional 3 -hour summer course has a larger negative impact with base salary falling by $\$ 4,245$. Teaching additional graduate hours has no significant impact on base salary. Apparently, however, stellar teaching is rewarded as those who reported receiving a teaching award at any time in their career have a significant increase in base salary.

Leadership to the department or institution does significantly increase base salary as both committees Chaired and the number of years as department chair are significantly positive. Service as a committee member, however, demonstrates no significant marginal impact on base salary.

The empirical estimates show a concave experience-earnings profile, which is considered a stylized fact in non-academic markets and common in the literature for academics. ${ }^{3}$ The estimates for seniority, however, provide additional fodder for the debate over the seniority-earnings profile. In this sample, there are positive returns to seniority, consistent with Barbezat's (2004) finding for academics and with the evidence from non-academic markets. ${ }^{4}$ It is contrary, however, to the results of markets for academic economists, as found in Moore et al. (2007) and Bratsberg et al. (2010).

Neither gender nor country of origin significantly affects pay. Graduating from a top Ph.D. program and pursuing publication both contribute positively to base salary. Taking an additional year to complete the doctoral program consulting activities do not significantly influence base salary.

\section{DOES THE TEACHING TAX EXIST FOR ECONOMISTS AT BOTH DOCTORAL AND NON-DOCTORALGRANTING INSTITUTIONS?}

Due to the extensive nature of the data set, we are able to investigate the existence of a teaching tax for economists at doctoral and non-doctoral granting institutions, a distinction which is new to the literature. Columns 2 and 3 of Table 1 present descriptive statistics for these two groups. The average economist at doctoral granting institutions earns almost $\$ 20,000$ more than peers at non-doctoral granting institutions. On average, economists at doctoral granting institutions teach fewer undergraduate hours (7.92 as compared to 13.13) and more graduate hours

\footnotetext{
${ }^{3}$ The quadratic terms describing experience are jointly significant at the 5 percent level.

${ }^{4}$ The model was also tested by using only tenured professors and by entering seniority in a quadratic fashion. The primary conclusions are robust across all specifications.
} 
(3.45 versus 2.01). Peers at non-doctoral granting institutions teach more credit hours in the summer. Service loads are roughly equivalent. It is not surprising that both the scholarly productivity index and number of books published is higher for economists at doctoral granting institutions.

Does the teaching tax exist for both groups? Columns 2 and 3 of Table 3 present OLS estimations for both groups. While the magnitude varies, the undergraduate teaching load is significantly negative for both subsamples. Economists at doctoral granting (non-doctoral granting) institutions on average earn $\$ 5,787(\$ 1,625)$ less when increasing undergraduate teaching load by three credit hours. Teaching an additional graduate course has an insignificant impact on base salary for both subgroups while only economists at doctoral granting schools see a reduction in base salary due to summer teaching.

One additional note of interest found when examining the subgroups is the marginal impact of publishing an additional quality and co-author adjusted publication. While significantly positive for both groups, when evaluated at the mean, economists at non-doctoral institutions earn an additional $\$ 1,050$ while their peers at doctoral universities earn only an additional $\$ 482$ for a similar quality- and coauthor-adjusted peer reviewed publication. Economists at non-doctoral granting schools publish five times less and have $\$ 20,000$ less in base pay than their peers at doctoral granting institutions. At the margin, however, there remains a larger financial incentive for these economists to publish.

\section{CONCLUSION}

The use of person-specific data for economists across all types of public academic institutions provides several insights to the wage equation for academic economists. First, this study confirms the alignment of the academic incentive structure with the underlying value of scholarship in an academic institution, i.e. scholarship pays off. Interestingly, though, the richness of this data set allows for a better understanding of that payoff. For while economists at doctoral granting institutions earn more on average than their counterparts at non-doctoral granting institutions, the marginal benefit for additional publications is higher for those economists at non-doctoral granting institutions.

Most importantly, the study validates the recent findings of Binder et al. (2012) that the incentive structure at academic institutions imposes a teaching tax. Whether at doctoral or non-doctoral granting institutions, the marginal cost of teaching undergraduates is significant although there is a positive return to award-winning teaching. Thus, despite the inherent educational mission of the Academy, this study supports the irony of Fairweather's (2005) conclusion that “...spending more time on teaching, particularly classroom instruction, still means lower pay."

\section{AUTHOR INFORMATION}

Blakely Fox Fender is Professor of Economics and J. Armistead Brown Chair of Business Administration at Millsaps College in Jackson, MS. She received her Ph.D. at the University of Texas.

E-mail: blakely.fender@millsaps.edu.

Susan Washburn Taylor, (corresponding author) is Professor of Economics and Selby and Richard McRae Chair of Business Administration at Millsaps College in Jackson, MS. She received her Ph.D. at Louisiana State University. Email: susan.taylor@millsaps.edu.

Kimberly Gladden Burke is Dean of the Else School of Management and Professor of Accounting at Millsaps College in Jackson, MS. She received her Ph.D. from Oklahoma State University. Email: kim.burke@millsaps.edu.

\section{REFERENCES}

Barbezat, D. A. (2003). From Here to Seniority. New Directions for Institutional Research, 117, 21-47. Barbezat, D. A. (2004). Revisiting the Seniority Wage Effect for Faculty. Economic Letters, 82(2), 289-94. Binder, M., Chermak, J., Krause, K. \& Thatcher, J. (2012). The Teaching Penalty in Higher Education: Evidence 
from a Public Research University. Economics Letters, 117, 39-41.

Bodenhorn, H. (1997). Teachers, and Scholars Too: Economic Scholarship at Elite Liberal Arts Colleges. Journal of Economic Education, 28(4), 323-36.

Blackaby, D., Booth, A. L., \& Frank, J. (2005). Outside Offers and the Gender Pay Gap: Empirical Evidence from the UK Academic Labour Market. The Economic Journal, 115(February), F81-F107.

Bratsberg, B., Ragan, J. F., \& Warren, J. T. (2010). Does Raiding Explain the Negative Returns to Faculty Seniority? Economic Inquiry, 48(3), 704-721.

Carlin, P. S., Kidd, M. P., Rooney, P. M., \& Denton, B. (2013). Academic Wage Structure by Gender: The Roles of Peer Review, Performance, and Market Forces. Southern Economic Journal, 80(1),127-46.

Fairweather, J. S. (2005.) Beyond the Rhetoric: Trends in the Relative Value of Teaching and Research in Faculty Salaries. The Journal of Higher Education, 76(4), 401-422.

Fender, B. F., Taylor, S. W., \& Burke. K. G. (2005). Making the Big Leagues: Factors Contributing to Publication in Elite Economics Journals. Atlantic Economic Journal, 33, 93-103.

Hammermesh, D. S. \& Pfann G. A. (2012). Reputation and Earnings: The Roles of Quality and Quantity in Academe. Economic Inquiry, 50(1), 1-16.

Laband, D.N. \& Piette, M. (1994). The Relative Impact of Economics Journals: 1970-1990. Journal of Economic Literature, 32(2), 640-66.

Moore, W. J., Newman, R. J., \& Turnbull, G. K.. (1998). Do Academic Salaries Decline with Seniority? Journal of Labor Economics, 16:352-66.

Moore, W. J., Newman, R. J,. \& Terrell, D. (2007). Academic Pay in the United Kingdom and the United States: The Differential Returns to Productivity and the Lifetime Earnings Gap. Southern Economic Journal, 73(3): 717-732.

O’Keefe, S.O. \& Wang, T. (2013). Publishing Pays: Economists' Salaries Reflect Productivity. The Social Science Journal, 50: 45-54.

Taylor, S..W., Fender, B. F \& Burke, K. G. (2006). Unraveling the Productivity of Academic Economists: The Opportunity Costs of Teaching and Service. Southern Economic Journal, 72(4), 846-59.

Takahashi, A. M., \& Takahashi, S. (2011). Gender Salary Differences in Economics Departments in Japan. Economics of Education Review, 30: 1306-1319. 


\section{TABLES}

Table 1. Summary Statistics for Faculty

\begin{tabular}{|c|c|c|c|}
\hline \multicolumn{4}{|c|}{ (Standard Deviations Reported in Parentheses) } \\
\hline & (1) & $(2)$ & (3) \\
\hline & Aggregate Sample & $\begin{array}{c}\text { Doctoral Granting } \\
\text { Institutions }\end{array}$ & $\begin{array}{c}\text { Non-Doctoral Granting } \\
\text { Institutions }\end{array}$ \\
\hline Salary & $\begin{array}{l}\$ 87,335.79 \\
(31,785.75) \\
\end{array}$ & $\begin{array}{l}\$ 96,460.82 \\
(37,609.33) \\
\end{array}$ & $\begin{array}{l}\$ 77,399.64 \\
(19,741.06) \\
\end{array}$ \\
\hline \multicolumn{4}{|l|}{ Teaching Characteristics } \\
\hline Undergraduate Load & $\begin{array}{l}10.42 \\
(6.11) \\
\end{array}$ & $\begin{array}{c}7.92 \\
(4.25) \\
\end{array}$ & $\begin{array}{l}13.13 \\
(6.67) \\
\end{array}$ \\
\hline Graduate Load & $\begin{array}{c}2.76 \\
(2.92)\end{array}$ & $\begin{array}{c}3.45 \\
(2.66)\end{array}$ & $\begin{array}{c}2.01 \\
(3.00)\end{array}$ \\
\hline Summer Hours & $\begin{array}{c}1.45 \\
(2.31)\end{array}$ & $\begin{array}{c}0.65 \\
(1.45)\end{array}$ & $\begin{array}{c}2.31 \\
(2.73)\end{array}$ \\
\hline Teaching Awards & $\begin{array}{c}1.31 \\
(1.76)\end{array}$ & $\begin{array}{c}1.42 \\
(1.85)\end{array}$ & $\begin{array}{c}1.20 \\
(1.65)\end{array}$ \\
\hline \multicolumn{4}{|l|}{ College Service Load } \\
\hline Committees & $\begin{array}{c}2.55 \\
(1.47) \\
\end{array}$ & $\begin{array}{c}2.45 \\
(1.41) \\
\end{array}$ & $\begin{array}{c}2.67 \\
(1.54) \\
\end{array}$ \\
\hline Committees Chaired & $\begin{array}{c}0.90 \\
(0.88) \\
\end{array}$ & $\begin{array}{c}0.91 \\
(0.92) \\
\end{array}$ & $\begin{array}{c}0.89 \\
(0.84) \\
\end{array}$ \\
\hline Years as Department Chair* & $\begin{array}{c}2.95 \\
(1.51) \\
\end{array}$ & $\begin{array}{c}2.68 \\
(1.38) \\
\end{array}$ & $\begin{array}{c}2.95 \\
(1.91) \\
\end{array}$ \\
\hline \multicolumn{4}{|l|}{ Publication History } \\
\hline QC Publications & $\begin{array}{c}12.18 \\
(19.73) \\
\end{array}$ & $\begin{array}{c}19.53 \\
(24.65) \\
\end{array}$ & $\begin{array}{c}4.16 \\
(5.56) \\
\end{array}$ \\
\hline Books & $\begin{array}{c}1.05 \\
(2.31) \\
\end{array}$ & $\begin{array}{c}1.33 \\
(2.18) \\
\end{array}$ & $\begin{array}{c}.74 \\
(2.41) \\
\end{array}$ \\
\hline \multicolumn{4}{|l|}{ Personal Characteristics } \\
\hline Experience & $\begin{array}{l}19.61 \\
(8.95) \\
\end{array}$ & $\begin{array}{l}19.57 \\
(9.62) \\
\end{array}$ & $\begin{array}{l}19.64 \\
(8.22) \\
\end{array}$ \\
\hline Seniority & $\begin{array}{l}16.81 \\
(9.32)\end{array}$ & $\begin{array}{c}16.92 \\
(10.14)\end{array}$ & $\begin{array}{l}16.69 \\
(8.39)\end{array}$ \\
\hline Male & $\begin{array}{c}0.80 \\
(0.40)\end{array}$ & $\begin{array}{c}0.82 \\
(0.39)\end{array}$ & $\begin{array}{c}0.78 \\
(0.42)\end{array}$ \\
\hline Foreign & $\begin{array}{c}0.06 \\
(0.24) \\
\end{array}$ & $\begin{array}{c}0.05 \\
(0.22) \\
\end{array}$ & $\begin{array}{l}0.08 \\
(.27)\end{array}$ \\
\hline Top Ph.D. Program & $\begin{array}{c}0.28 \\
(0.45) \\
\end{array}$ & $\begin{array}{c}0.38 \\
(0.49) \\
\end{array}$ & $\begin{array}{c}0.17 \\
(0.37) \\
\end{array}$ \\
\hline Review before Ph.D. & $\begin{array}{c}0.53 \\
(0.87)\end{array}$ & $\begin{array}{c}0.68 \\
(1.01)\end{array}$ & $\begin{array}{c}0.37 \\
(0.66)\end{array}$ \\
\hline Years to Ph.D. & $\begin{array}{c}5.55 \\
(1.96) \\
\end{array}$ & $\begin{array}{c}5.20 \\
(1.79) \\
\end{array}$ & $\begin{array}{c}5.92 \\
(2.07) \\
\end{array}$ \\
\hline Consulting & $\begin{array}{c}0.38 \\
(0.49) \\
\end{array}$ & $\begin{array}{c}0.39 \\
(0.49) \\
\end{array}$ & $\begin{array}{c}0.38 \\
(0.49)\end{array}$ \\
\hline \multicolumn{4}{|l|}{ Institutional Characteristics } \\
\hline Doctoral Granting Institution & $\begin{array}{c}.52 \\
(0.50)\end{array}$ & & \\
\hline Number of observations & 188 & 98 & 90 \\
\hline
\end{tabular}

*conditioned on chair experience 
Table 2. Variable Definitions

\begin{tabular}{|c|c|}
\hline Salary & Nine-month base salary for the 2003-2004 academic year. \\
\hline \multicolumn{2}{|l|}{ Teaching Characteristics } \\
\hline Undergraduate Load & The number of undergraduate credit hours typically taught during an academic year. \\
\hline Graduate Load & The number of graduate credit hours typically taught during an academic year. \\
\hline Summer Hours & The number of credit hours typically taught during the summer. \\
\hline Teaching Awards & The number of teaching awards received. \\
\hline \multicolumn{2}{|l|}{ College Service Load } \\
\hline Committees & $\begin{array}{l}\text { The average number of committees on which a person service in a typical year, exclusive } \\
\text { of the average number of committees an individual chairs. }\end{array}$ \\
\hline Committees Chaired & The average number of committees a person chairs in a typical year. \\
\hline Years as Department Chair* & $\begin{array}{l}\text { The number of years an individual has served as department chair or program director in } \\
\text { the last } 5 \text { years }\end{array}$ \\
\hline \multicolumn{2}{|l|}{ Publication History } \\
\hline QC Publications & The number of quality and coauthor adjusted publications. \\
\hline Books & The number of books published. \\
\hline \multicolumn{2}{|l|}{ Personal Characteristics } \\
\hline Experience & Number of years since completion of the Ph.D. \\
\hline Seniority & Number of years at the current institution. \\
\hline Male & A dummy variable equal to one for males. \\
\hline Foreign & $\begin{array}{l}\text { A dummy variable equal to one if the individual received an undergraduate degree outside } \\
\text { the U.S. }\end{array}$ \\
\hline Top Ph.D. Program & A dummy variable equal to one for graduates from a top Ph.D. program \\
\hline Review before Ph.D. & $\begin{array}{l}\text { The number of manuscripts under review at referred journals before the individual's first } \\
\text { academic position. }\end{array}$ \\
\hline Years to Ph.D. & The number of years taken to obtain a Ph.D. \\
\hline Consulting & A dummy variable equal to one for individuals who provide consulting services. \\
\hline \multicolumn{2}{|l|}{ Institutional Characteristics } \\
\hline Doctoral Granting Institution & A dummy variable equal to one if the highest degree offered is a doctoral degree. \\
\hline
\end{tabular}


Table 3. Determinants of Earnings for Faculty

Dependent Variable $=$ Natural Log of Salary

\begin{tabular}{|c|c|c|c|}
\hline & (1) & (2) & (3) \\
\hline & Aggregate Sample & $\begin{array}{c}\text { Doctoral Granting } \\
\text { Institutions }\end{array}$ & $\begin{array}{c}\text { Non-Doctoral Granting } \\
\text { Institutions }\end{array}$ \\
\hline \multicolumn{4}{|l|}{ Teaching Characteristics } \\
\hline Undergraduate Load & $\begin{array}{c}-0.010 * * \\
(3.03)\end{array}$ & $\begin{array}{c}-0.020 * * \\
(2.32)\end{array}$ & $\begin{array}{c}-0.007 * * \\
(1.95)\end{array}$ \\
\hline Graduate Load & $\begin{array}{l}0.005 \\
(0.80)\end{array}$ & $\begin{array}{c}--0.006 \\
(0.44)\end{array}$ & $\begin{array}{l}0.005 \\
(0.65)\end{array}$ \\
\hline Summer Hours & $\begin{array}{c}-0.016^{* *} \\
(2.08)\end{array}$ & $\begin{array}{l}-0.037 \\
(1.94)\end{array}$ & $\begin{array}{l}-0.001 \\
(0.08)\end{array}$ \\
\hline Teaching Awards & $\begin{array}{c}0.035^{* *} \\
(3.74)\end{array}$ & $\begin{array}{l}0.048 \\
(3.44)\end{array}$ & $\begin{array}{l}0.035 \\
(2.75)\end{array}$ \\
\hline \multicolumn{4}{|l|}{ College Service Load } \\
\hline Committees & $\begin{array}{l}0.005 \\
(0.47)\end{array}$ & $\begin{array}{l}-0.018 \\
(1.00)\end{array}$ & $\begin{array}{l}0.02 * \\
(1.64)\end{array}$ \\
\hline Committees Chaired & $\begin{array}{c}0.032 * * \\
(1.65) \\
\end{array}$ & $\begin{array}{l}0.037 \\
(1.24) \\
\end{array}$ & $\begin{array}{l}0.017 \\
(0.66) \\
\end{array}$ \\
\hline Years as Department Chair* & $\begin{array}{l}0.021^{* * *} \\
(2.00)\end{array}$ & $\begin{array}{l}0.026^{*} \\
(1.51)\end{array}$ & $\begin{array}{l}0.016 \\
(1.27)\end{array}$ \\
\hline \multicolumn{4}{|l|}{ Publication History } \\
\hline QC Publications & $\begin{array}{c}0.006^{* *} \\
(5.83)\end{array}$ & $\begin{array}{l}0.01 * * \\
(3.71)\end{array}$ & $\begin{array}{c}0.014 * * \\
(3.65)\end{array}$ \\
\hline Books & $\begin{array}{c}0.015^{* *} \\
(1.83)\end{array}$ & $\begin{array}{l}0.017 \\
(1.23) \\
\end{array}$ & $\begin{array}{l}0.009 \\
(0.88)\end{array}$ \\
\hline \multicolumn{4}{|l|}{ Personal Characteristics } \\
\hline Experience & $\begin{array}{l}0.017 * * \\
(2.33)\end{array}$ & $\begin{array}{l}0.01^{*} \\
(1.34)\end{array}$ & $\begin{array}{c}0.023 * * \\
(2.08)\end{array}$ \\
\hline Experienced-Squared & $\begin{array}{c}0.000^{* * *} \\
(2.85)\end{array}$ & $\begin{array}{l}0.000^{*} \\
(1.78)\end{array}$ & $\begin{array}{c}-0.001 * * \\
(2.30)\end{array}$ \\
\hline Seniority & $\begin{array}{c}0.007 * * \\
(1.96)\end{array}$ & $\begin{array}{l}0.003 \\
(0.55) \\
\end{array}$ & $\begin{array}{l}0.01 * * \\
(2.27)\end{array}$ \\
\hline Male & $\begin{array}{l}-0.008 \\
(0.21) \\
\end{array}$ & $\begin{array}{l}0.048 \\
(0.69) \\
\end{array}$ & $\begin{array}{c}-0.088 * * \\
(1.85) \\
\end{array}$ \\
\hline Foreign & $\begin{array}{l}0.001 \\
(0.02)\end{array}$ & $\begin{array}{l}-0.080 \\
(0.69)\end{array}$ & $\begin{array}{l}0.0432 \\
(0.58)\end{array}$ \\
\hline Top Ph.D. Program & $\begin{array}{l}0.096^{* * *} \\
(2.51)\end{array}$ & $\begin{array}{l}0.066 \\
(1.20)\end{array}$ & $\begin{array}{c}0.147 * * \\
(2.57)\end{array}$ \\
\hline Review before Ph.D. & $\begin{array}{c}0.036^{* *} \\
(1.90)\end{array}$ & $\begin{array}{l}0.027 \\
(1.02)\end{array}$ & $\begin{array}{c}0.0414^{*} \\
(1.31)\end{array}$ \\
\hline Years to Ph.D. & $\begin{array}{l}-0.011 \\
(1.23) \\
\end{array}$ & $\begin{array}{r}-0.011 \\
(0.73) \\
\end{array}$ & $\begin{array}{r}-0.010 \\
(1.02) \\
\end{array}$ \\
\hline Consulting & $\begin{array}{l}0.040 \\
(1.21) \\
\end{array}$ & $\begin{array}{l}0.045 \\
(.086) \\
\end{array}$ & $\begin{array}{l}0.020 \\
(0.49) \\
\end{array}$ \\
\hline \multicolumn{4}{|l|}{ Institutional Characteristics } \\
\hline $\begin{array}{l}\text { Doctoral Granting } \\
\text { Institution }\end{array}$ & $\begin{array}{l}-0.026 \\
(0.70)\end{array}$ & & \\
\hline $\begin{array}{l}\text { Adjusted R-Squared } \\
\text { Number of observations }\end{array}$ & $\begin{array}{c}0.575 \\
188\end{array}$ & $\begin{array}{c}0.556 \\
98\end{array}$ & $\begin{array}{c}0.523 \\
90\end{array}$ \\
\hline
\end{tabular}

Absolute value of t-statistic in parentheses. ${ }^{* *}$ Significant at the $5 \%$ level. ${ }^{*}$ Significant at the $10 \%$ level. 